\title{
Culture Learning Management Al-Quran Model Tilawati to Improve Student Character
}

\author{
*Umar Jaeni' ${ }^{1}$, Ismet Basuki ${ }^{2}$, Moedjiarto ${ }^{3}$ \\ 1,2,3 Doctoral Program of Education Management, Universitas Negeri Surabaya, Surabaya, Indonesia
}

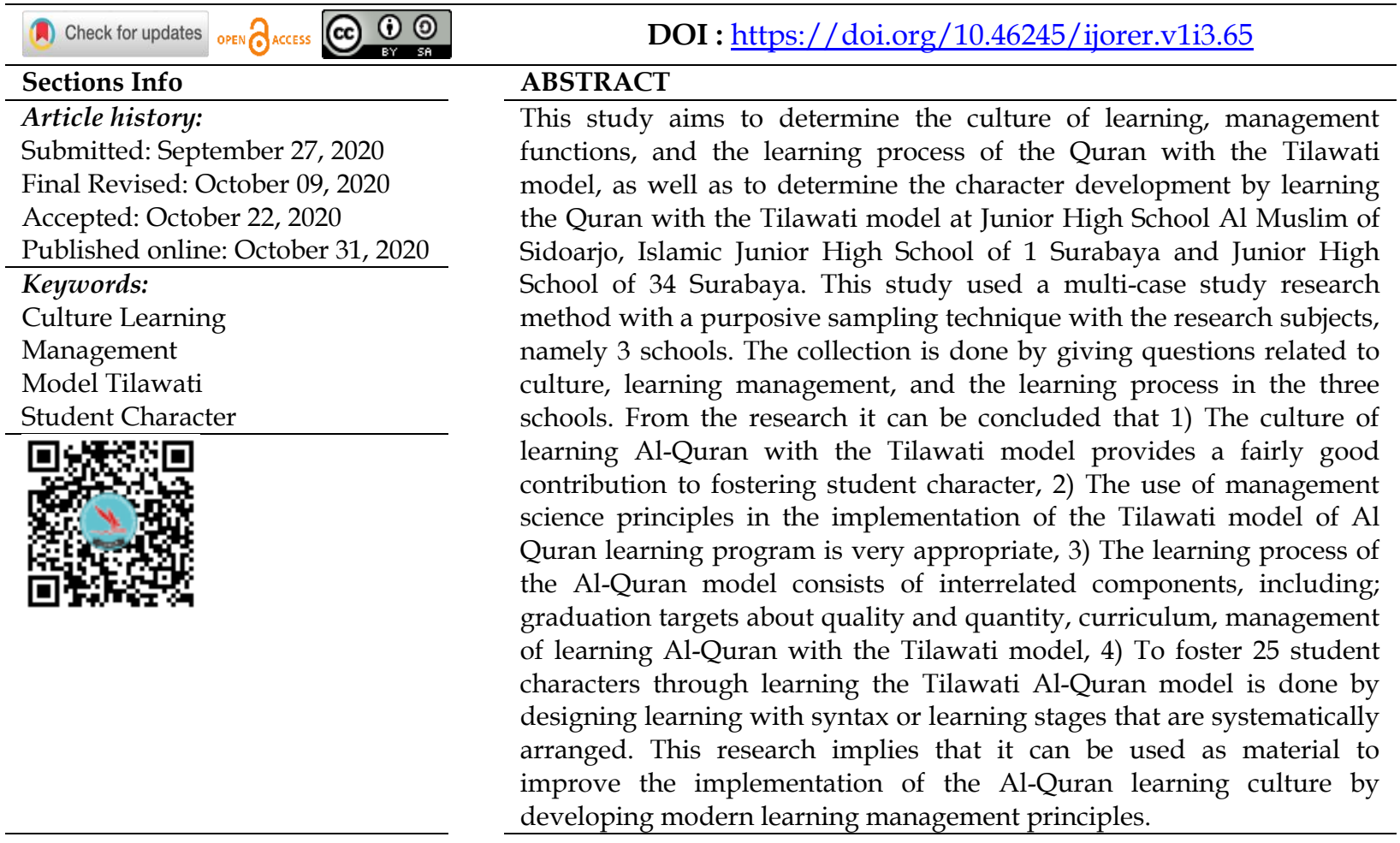

\section{INTRODUCTION}

Education is one of the gates to scholarship in contributing to a country both domestically and abroad (Quan et al., 2013). On this basis, we can know that education is a basic human need (Sulaiman \& Wibowo 2016; Lemke \& Johnson, 2013). To improve the quality of education, professional human resources are needed (Firestone et al., 2020; Cheung et al., 2011). Professional teachers must have important factors that have an impact on student learning outcomes (Jennifer et al., 2017; Antonia et al., 2020). Besides, the teacher must be able to cultivate student character (Deswati et al., 2020; Umi et al., 2018; Sofian, 2018). Character education in Indonesia has increased significantly after the government has established the promotion of character education in the world of education (Barus \& Munkasi, 2019; Rokhman et al., 2014). This is because education is considered the center of excellence in preparing human superior character (Rokhmana, 2014; Lyer, 2017).

The National Education Law mandates that educational attainment does not only produce intelligence and skills but must produce human character (Barus \& Munkasi, 2019) because there is no point in mastering skills and intellectuals without a dissertation of faith and character (Ikhwan, 2014; Adawiah, 2018). The characters possessed by students have different characteristics (Kane et al., 2017; Zainal \& Sujak, 2011). Apart from teaching about spirituality, the role of religion is also very important 
(Faud, 2014). The most substantial development is moral (Malik et al., 2015), and moral development (Ikhwan et al., 2019). Cultivating education through character learning can lead students to more about the meaning of courtesy and good behavior (Kane et al., 2017; Fua et al., 2018; Utomo \& Juul, 2017). This is similar to learning in Islam (Che Noh et al., 2019).

Islamic religious education plays an important role in controlling the strength of Industry 4.0 through character education (Anwar et al., 2018; Fua et al., 2018). The basics of character education in a religion can be found in the holy book. In Islam, character education can be learned through or morals in the Al Quran (Hakim, 2014). The formation of Al-Quran education includes reading, knowing, and understanding the values contained therein. Learning the Koran is teaching to read the Koran properly and correctly so that you can read the Koran according to the correct reading rules, namely the rules of recitation (Khannah \& Waqfin, 2019). Through the cultivation of character through the Tilawati learning model, it can lead students to continue to increase their potential in the world of education and develop information technology with Islamic characters (Othman et al., 2017; Dalmeri, 2014).

Based on this background, the study formulated research on the culture of learning Al-Qur'an through the Tilawati model to foster the character of students. This research is packaged as an effort to analyze the culture of management from several schools that have taught the Tilawati method to students or students.

\section{Problem of Research}

1. How to cultivate Tilawati model of Al-Quran learning to foster character in Junior High School Al Muslim of Sidoarjo, Islamic Junior High School of 1 Surabaya, and Junior High School of 34 Surabaya?

2. How does the management function of the Tilawati Al-Quran learning model to foster character at Junior High School Al Muslim of Sidoarjo, Islamic Junior High School of 1 Surabaya, and Junior High School of 34 Surabaya?

3. How is the process of learning Al-Quran with the Tilawati model to foster character at Junior High School Al Muslim of Sidoarjo, Islamic Junior High School of 1 Surabaya, and Junior High School of 34 Surabaya?

4. How is the process of character building in learning Al-Quran with the recitation model at Junior High School Al Muslim of Sidoarjo, Islamic Junior High School of 1 Surabaya, and Junior High School of 34 Surabaya?

\section{Focus of Research}

According to the research question above, the purpose of this study is to find out more deeply and to describe the following:

1. The culture of learning Al-Quran model of women's style to foster character at Junior High School Al Muslim Sidoarjo, Islamic Junior High School 1 Surabaya, and Junior High School 34 Surabaya.

2. The management function of learning Al Quran with the model of the style to foster character at Junior High School Al Muslim Sidoarjo, Islamic Junior High School 1 Surabaya, and Junior High School 34 Surabaya.

3. The process of learning the Qur'an with a Tilawati model to foster character at Junior High School Al Muslim Sidoarjo, Islamic Junior High School 1 Surabaya, and Junior High School 34 Surabaya. 
4. Character building by learning the Quran with the recitation model at Junior High School Al Muslim Sidoarjo, Islamic Junior High School 1 Surabaya, and Junior High School 34 Surabaya.

\section{RESEARCH METHOD \\ General Background}

This type of research uses a multi-case study at Junior High School Al Muslim of Sidoarjo, Islamic Junior High School of 1 Surabaya, and Junior High School of 34 Surabaya. This research is carried out in-depth with individuals, groups, and organizations to get a goal they want to achieve.

\section{Data Collection}

The collection is done by giving questions related to culture, learning management, and the learning process in the three schools. The subjects of the study were the principal, the coordinator of the Al-Quran teaching teacher, the Tilawati model, the Al Quran teacher, the Tilawati model of Al Quran learning supervisor, and the students. The research subjects were taken using purposive sampling and snowball sampling techniques. The collection technique is carried out using observation (observation), interview (interview), questionnaire (questionnaire), documentation, and a combination of the four or triangulation.

\section{Data Analysis}

Analysis of research data begins with the process of collecting data according to information from research subjects, then after the data is obtained, the data selection process is carried out or called condensation. Followed by the process of presenting data and ending with concluding. Conclusion drawing is done in two ways, namely single data analysis and cross-case data analysis.

\section{Procedure of Research}

First, the pre-field stage (first stage) is carried out, namely before conducting the research, the researcher first contemplates ideas and ideas on social problems in the community environment related to education. Then the fieldwork stage (second stage) is carried out, which is data mining, data mining is carried out using observation, interviews, and documentation study. Observations are generally carried out with the maintenance of various things, the condition of the school, the number of study groups, the implementation of the Quranic learning process with the Tilawati method, and the observation of the teacher's attitude and appearance. Then the third stage, namely the researcher applying the results of the research carried out.

The data validity test in this study used 4 standards as proposed by Lincoln and Guba including credibility tests (internal validity), transferability (external validity), dependability (reliability), and confirmability (objectivity). The entire audit research process was carried out by 3 experts, so based on the validity test it was declared worthy of being researched.

\section{RESULTS AND DISCUSSION}

Character Culture at Junior High School Al Muslim of Sidoarjo, Islamic Junior High School of 1 Surabaya, and Junior High School of 34 Surabaya.

\section{Character culture at Junior High School Al Muslim of Sidoarjo.}


The character culture at Junior High School of AL Muslim of Sidoarjo is analyzed, among other things, from getting used to being on time and good habits at school. The good habit that this school does is that students arrive promptly at 6.40 minutes later the teacher is ready to greet students by greeting each student who will enter the school. Then with the habit of reading the Al Quran short letters in juz amma, and praying Dhuha.

The habit of welcoming students and praying Duha together is a school program to instill character for students to be disciplined and to train leadership as expressed by Mrs. Ika as follows.

"As soon as the children arrived, the children entered the school gate and put their bags in the classroom and then went straight into the hall. At 6.45 the children recited the Koran together to read the Koran, including the $A l$ Waqiah letter and the short letters from Juz Amma. Exactly at 7.00 the recitation together ended then together praying Duha. This is to train leadership so that children have a brave character, they are given the task of being maudlin or carrying out the call to prayer and become prayer leaders and giving a seven-minute lecture." (Deputy Principal. 11 Nov 2019.).

Based on the results of the interviews conducted by researchers, they cannot describe the results of the interviews as a whole, but the results of describing the character culture of schools at Junior High School of AL Muslim of Sidoarjo are as follows:

Table 1. The character culture of schools in Junior High School Al Muslim of Sidoarjo.

\begin{tabular}{cl}
\hline No. & \multicolumn{1}{c}{ The Character Culture Of Schools } \\
\hline 1 & The character education policy is a Foundation policy. \\
2 & $\begin{array}{l}\text { The Tilawati model of the Al Quran learning program is a compulsory } \\
\text { additional subject that is designated as an integral part of the process of } \\
\text { developing student character to realize the vision of producing a leader who is } \\
\text { Rahmatan Lil Naturalin. }\end{array}$ \\
3 & $\begin{array}{l}\text { The policy of the Al Quran learning program at Al Muslim Junior High School } \\
\text { has defined general objectives and operational objectives. }\end{array}$ \\
4 & $\begin{array}{l}\text { To implement the policy, personnel are required to be responsible for the } \\
\text { program is launched. }\end{array}$ \\
5 & $\begin{array}{l}\text { The character building in Junior High School Al Muslim is creatively designed to } \\
\text { be integrated with general subjects, integrated religious activities, and the Al }\end{array}$ \\
6 & $\begin{array}{l}\text { Quran Tilawati learning program. } \\
\text { The Foundation allocates sufficient time for learning Al Quran. } 4 \text { times a week }\end{array}$ \\
7 & Foundations bear full responsibility for all operational costs of the Al Quran \\
learning program.
\end{tabular}

\section{Cultivating characters in Islamic Junior High School of 1 Surabaya}

In the character culture at this school, morning activities in daily life are like the $\mathrm{Al}$ Muslim Sidoarjo Middle School. Al Quran Tilawati learning activities and Dhuha prayer activities in congregation and other religious activities are efforts to instill character. As stated by Mr. Witono as the principal as follows.

"The reading of the Yasin letter and the waqiah letter, the Dhuha prayer every morning in grades VIII and IX read istighosyah, practice mukhadoroh (giving speeches), the art of qosidah and promises and assigns the task of leading prayers especially for students from the guidance of 
reading the Al Quran which reads well are our efforts to instill leadership character, discipline, dare to appear and have a softer spirit." (W. Principal 22 July 2019).

The results of the analysis presented above are one of the results of interviews conducted by researchers. The following is the recapitulation of character culture Islamic Junior High School of 1 Surabaya.

Table 2. Character culture Islamic Junior High School of 1 Surabaya.

\begin{tabular}{cl}
\hline No & Character Culture \\
\hline 1 & The background of the birth of the character education program policy is because \\
of the many student behavior that is far from the values of morality and \\
politeness. From this background, the policy for the Al Quran learning program \\
is part of one of the ways and efforts to cultivate student character. \\
The general objective of the Al Quran learning program at MTs. Negeri 1 \\
Surabaya to realize the vision and mission of madrassas to provide provisions for \\
IMTEK and IMTAQ and instill love characters for their holy chaplain. \\
Planning and program activities refer to general targets that define students' basic \\
training skills. After the basic recitation, memorize Al Quran juz 30 or zuz amma \\
Evaluation of the Al Quran learning program is carried out on two things, first \\
about the target learning outcomes and secondly evaluating teacher performance. \\
The general evaluation is carried out by the person in charge of the program \\
while the technical evaluation is carried out by the Al Quran teacher coordinator. \\
The implementation of the Al Quran learning program policy requires \\
responsible personnel. Responsible officers are formed in stages starting from the \\
principal, the person in charge of the program, the Al Quran teacher coordinator, \\
and the classroom teacher. Thus there are 4 levels of the person in charge. \\
The integration of character planting is more integrated with school activities, \\
both religious activities, and other activities, while integration with other subjects \\
has not been implemented. \\
Learning lasts for 4 semesters. Implementation of learning in one week 4 \\
meetings. The learning target is not up to 30 juz \\
Funding for Al-Quran learning activities is financed from BOS funds, the source \\
of which is from the central Indonesian Ministry of Religion. However, these \\
costs are not sufficient for operational costs, so parents are given the burden to \\
participate in paying activity fees
\end{tabular}

\section{Character culture of Junior High School of 34 Surabaya.}

The effort to instill character education in students at Junior High School of 34 Surabaya is carried out in a comprehensive and mutually supportive manner from all activities at school. School activities that support character are carried out from students entering school to returning home as conveyed by Mrs. Siti Maftuhatin as follows.

"Every morning the children when entering the gate of the schoolyard the children are greeted by the mother and the teacher for the male students to shake hands with the teacher while the female students shake hands with the teacher, this separation is done with the aim that the children can immediately perform Dhuha prayers without doing ablution first so that the children can get used to taking ablution from the house. Dhuha prayers are held every Tuesday, Wed, and Thursday. The implementation of the Duha 
prayer starts at 0.6.30-7.20. The series of Dhuha prayers are continued by reading short letters in zuz 30 or zuz amma and learning to memorize the $A l$ Quran". (W. PAI teacher / Al Quran teacher coordinator. 28 October 2019)

From the presentation of the data above, it appears that State Junior High School of 34 Surabaya has made every effort to make students have good character. One of the means to cultivate the character of students is through religious activities with the habituation of Dhuha prayers and congregational prayers. All of these activities are carried out in very compact cooperation between teachers with their respective duties and functions.

\section{Learning Management at Junior High School Al Muslim of Sidoarjo, Islamic Junior High School of 1 Surabaya, and Junior High School of 34 Surabaya. \\ 1. Learning Management at Junior High School Al Muslim of Sidoarjo.}

Learning Management which is carried out at Junior High School Al Muslim Sidoarjo is carried out with the hope that the quality of teachers will be better. This is as stated by Mrs. Aslachah as follows;

"We always conduct teacher training to strengthen abilities both in terms of reading quality, development of potential and skills because the fruit will not fall far from the tree, meaning that the teacher becomes a very important model and example in achieving successful learning outcomes. The good teacher then students will be good. To create quality teachers, we have a program in the form of training once a semester while the material is as needed. (W. Tilawati teacher general coordinator. 18 Nov 2019)."

The results of interviews related to learning management at Junior High School Al Muslim of Sidoarjo cannot all be described in this article, but there are several descriptions obtained by researchers in analyzing learning management as follows: Based on the description and data analysis above, the research findings are on the second focus, namely related to Al-Quran learning management model of Tilawati at Junior High School of AL Muslim can be presented as follows:

Table 3. Learning management at Junior High School Al Muslim of Sidoarjo.

\begin{tabular}{|c|c|}
\hline No. & Learning Management \\
\hline 1 & $\begin{array}{l}\text { The Tilawati model of Al Quran learning activity refers to several elements of } \\
\text { planning which include learning objectives, learning programs, the existence of } \\
\text { established regulations, and implementation procedures. }\end{array}$ \\
\hline 2 & $\begin{array}{l}\text { The curricular objective of learning Al Quran is to provide students with a proper } \\
\text { reading of the Quran according to the laws of tajwid }\end{array}$ \\
\hline 3 & $\begin{array}{l}\text { The Al Quran learning activity program has been completely structured } \\
\text { concerning student activities and teacher quality improvement activities }\end{array}$ \\
\hline 4 & $\begin{array}{l}\text { The existence of regulations as a binding for all } \mathrm{Al} \text { Quran teaching personnel. } \\
\text { Regulations are manifested in three types, namely written regulations in the MoU, } \\
\text { written regulations in the form of rules, and oral regulations. }\end{array}$ \\
\hline 5 & $\begin{array}{l}\text { From an organizational perspective, there is already a clear structure for the } \\
\text { division of labor, tasks, responsibilities, and authorities. }\end{array}$ \\
\hline 6 & $\begin{array}{l}\text { A clear structure provides clarity in carrying out duties and responsibilities for all } \\
\text { teachers }\end{array}$ \\
\hline 7 & In terms of implementation or actuating, it concerns the existence of guidance, \\
\hline
\end{tabular}




\section{No. \\ Learning Management}

direction, and synergy among stakeholders to function by their respective duties and responsibilities.

8 Forms of guidance and direction include briefing, personal guidance, motivation, and training

9 Meanwhile, the synergy developed by all parties is broadly not limited to learning the Koran, but also student issues

10 In terms of control of the implementation of Al Quran learning, it is carried out in a tiered manner starting from the highest level, namely the head of the education sector, general coordinator of Tilawati teachers, coordinator of Al Quran teacher units in junior high schools, Al Quran teachers who teach in class and school principals.

\section{Learning Management Islamic Junior High School of 1 Surabaya.}

In managing the learning management, there is an explanation of the instructional objectives of Al Quran learning carried out by the Al Quran teacher coordinator and the ranks of the teachers under him. This was as stated by Mrs. Umi Chanifah as the person in charge of the program as follows.

"I am entrusted by the madrasa as the person in charge of the Al Quran learning program. Madrasas already have general goals or institutional goals. The hope is how these madrasah children will have better character. We hope that this Al Quran learning program is a means to instill character values in students. The point is, I want with this program to read the Al-Quran for the children to be good and have the Al Quran memorization, thank God if you memorize a few juz. And we are eager that someday we will show the parents of students at the graduation ceremony and the children's ability to read the Koran. Meanwhile, to explain in more detail the objectives of the school are technically submitted to the Al Quran teachers. In this regard, they have advantages over me. I am just a general person, maybe I also still lack a lot of my Koran."(W. Public relations department. 29 July 2019).

The following is the result of a description of learning management from Islamic Junior High School of 1 Surabaya:

Tabel 4. Learning management at Islamic Junior High School of 1 Surabaya.

\begin{tabular}{cl}
\hline No & \multicolumn{1}{c}{ Learning Management } \\
\hline 1 & $\begin{array}{l}\text { In terms of planning for Al-Quran learning at State Islamic Junior High School, it } \\
\text { has institutional and curricular goals }\end{array}$ \\
2 & $\begin{array}{l}\text { The implementation of the Al Quran Tilawati learning program is left to Al Quran } \\
\text { teachers }\end{array}$ \\
3 & $\begin{array}{l}\text { To see the achievement of learning outcomes, the person in charge of the program } \\
\text { only needs to compare the lesson plans with the results achieved }\end{array}$ \\
4 & $\begin{array}{l}\text { The learning program has been structured in detail } \\
5\end{array}$ Planning and programs to run properly requires regulations. \\
6 & $\begin{array}{l}\text { Rules in more detail, Al Quran teachers make rules internally with the aim that } \\
\text { teachers are more disciplined }\end{array}$ \\
7 & $\begin{array}{l}\text { The stage of classifying students aims to see the basic abilities of students in } \\
\text { reading the Al-Quran, as a basis for class grouping }\end{array}$ \\
8 & $\begin{array}{l}\text { In terms of implementing control or controlling to maintain discipline and improve } \\
\text { the quality of Al-Quran learning at Islamic Junior High School of } 1 \text { Surabaya can }\end{array}$ \\
\hline
\end{tabular}




\section{Learning Management at Junior High School of 34 Surabaya}

School activities that lead to building student character at Junior High School of 34 Surabaya are quite diverse, including one of which is learning Al-Quran through learning the Tilawati model. However, no written policy is deemed very important in the form of a school decree as a reference and legal basis for the implementation of reciting activities. Policies regarding character education still generally refer to the school's vision and mission as conveyed by Mrs. Siti Maftuhatin as follows.

"Yes sir, ... indeed if the policy specifically regarding written character education activities at this school does not yet exist, including the recitation activities, we do not have a written policy, because at that time the principal agreed and supported the Al Quran reading program or reciting the Koran. this then we dare to run. As the basis for this Kaji program, we refer to the vision, mission, and culture of the school. The vision of State Junior High School 34 Surabaya is the realization of students with characteristics, achievements, knowledge, culture, and a drug-free environment. (W. PAI teacher / Al Quran reading and writing teacher coordinator. 28 October 2019). "

From the description of the data above, the research findings on the first focus relating to the culture of learning the Quran with the Tilawati model at Junior High School of 34 Surabaya can be presented as follows.

Table 5. Learning management of Junior High School of 34 Surabaya.

\begin{tabular}{|c|c|}
\hline No & Learning Management \\
\hline 1 & $\begin{array}{l}\text { The policy for implementing character education for students at Junior High School } \\
34 \text { Surabaya is based on findings of student behavior that is very inappropriate or } \\
\text { leads to juvenile delinquency. }\end{array}$ \\
\hline 2 & $\begin{array}{l}\text { Activities to foster student character at Junior High School } 34 \text { Surabaya are carried } \\
\text { out with various activities including religious activities such as Dhuha prayer, } \\
\text { Dzuhur prayer, Friday prayer, and other school activities }\end{array}$ \\
\hline 3 & $\begin{array}{l}\text { The Al Quran learning program at Junior High School } 34 \text { Surabaya is one part of } \\
\text { instilling student character as an answer to student behavior which has been a } \\
\text { problem in schools. }\end{array}$ \\
\hline 4 & $\begin{array}{l}\text { ter education policy through the } \mathrm{Al} \text { Quran learning program refers to } \\
\text { mission, and school culture }\end{array}$ \\
\hline 5 & $\begin{array}{l}\text { ning program have a very clear direction as } \\
\text { mission }\end{array}$ \\
\hline 6 & $\begin{array}{l}\text { The general objective of the Al Quran learning program policy is to make students } \\
\text { have more faith and piety character, like and get used to practicing worship and } \\
\text { love the holy book }\end{array}$ \\
\hline 7 & $\begin{array}{l}\text { The implementation of character education at Junior High School } 34 \text { Surabaya is } \\
\text { carried out comprehensively and is integrated with other activities }\end{array}$ \\
\hline 8 & $\begin{array}{l}\text { Evaluation of program implementation management has not been able to run } \\
\text { optimally. This is because the time allocation is very limited. }\end{array}$ \\
\hline
\end{tabular}

The Tilawati Model of Al Quran Chasing Process

1. The Process of Chasing The Tilawati Al-Quran at Junior High School Al Muslim of Sidoarjo. 
In the learning process at Junior High School Al Muslim Sidoarjo, the Tilawati Al Quran Learning Achievement Target is applied. The implementation of the principles of Tilawati learning is explained in more detail by Amari as follows. "InsyaAllah, the Al Quran teachers at Al Muslim Junior High School have all attended the standardization training for Tilawati teachers. They already have provisions on how to teach Tilawati and its principles. We always try to escort teachers to consistently implement the learning principles formulated by Tilawati. The principle of Tilawati learning that we always guard is first, Tilawati is taught practically. The point is to teach Tilawati without spelling but the sound of the letters is introduced immediately. Second, use the song rost. So since the beginning, students in learning the letters of the Koran are already using songs. Third, taught classically using visuals. It means that Tilawati learning is taught with a collective approach. Fourth, taught individually with the taking turns reading technique. This means that besides the classical approach there is also an individual approach, where children are assigned to read individually in turns. (W. Al Quran teacher coordinator for Junior High School. 14 December 2019). "

The results of the direct statement above are one of several results of interviews conducted by researchers in understanding the learning process of the Al-Quran model of Tilawati at Junior High School Al Muslim Sidoarjo. The following are some descriptions of the results of the learning process at Junior High School of AL Muslim Sidoarjo.

Table 6. The Learning process of Al Quran Model of Tilawati at Junior High School Al Muslim of Sidoarjo.

\begin{tabular}{cl}
\hline No. The Learning Process of Al Quran Model of Tilawati \\
\hline 1 & $\begin{array}{l}\text { All junior high school students after graduating must already know the Al Quran } \\
\text { which is marked by attending the graduation ceremony and hataman Al Quran }\end{array}$ \\
2 & $\begin{array}{l}\text { The curriculum used refers to the curriculum that has been established by the } \\
\text { Nurul Falah Foundation as a center for learning the Quran with the Tilawati } \\
\text { model. }\end{array}$ \\
3 & $\begin{array}{l}\text { There is a learning load in the form of face to face, assignments, and independent } \\
\text { activities set out in the lesson plan. }\end{array}$ \\
Tasks carried out by students in the learning process actively participate in every \\
activity instructed by the teacher. \\
The classroom is designed dynamically, moving class is open outside the \\
classroom. \\
Independent tasks in the form of memorizing versus of the Quran \\
10 Requirements to become a Tilawati model teacher, pass administration, have \\
the competence to teach the Qur'an with a Tilawati model proven by a certificate \\
of Tilawati model.
\end{tabular}

\section{The Process of Chasing Al-Quran Model Tilawati at Islamic Junior High School of 1 Surabaya.}

The target achievement of learning Al Quran Tilawati as a guideline and reference that must be taken by all teachers according to the class group being taught. Pak 
Zainul as an Al Quran Tilawati teacher has understood the graduation target that is his responsibility and has tried to meet these targets as described below.

"The children in volume III have now started preparation for their exams. Usually I teach Tilawati only one page per face to face, but because this is going to be a test, I do the exercises up to 4 pages so that the children will run more smoothly during the volume increase exam. Whereas for the target achievement of memorizing the target that must be memorized by children is 5 letters, while those who have not memorized it are required to deposit until they can finish. (W. Al Quran teacher volume III. September 10, 2019). "

Based on the description of the data above, the research findings on the third focus relating to the learning process of the Al Quran with the Tilawati model of Mts Negeri 1 Surabaya can be presented as follows.

Table 7. Learning Al-Quran model Tilawati at Islamic Junior High School of 1 Surabaya.

\begin{tabular}{|c|c|}
\hline No & Learning Al-Quran model Tilawati \\
\hline 1 & $\begin{array}{l}\text { About graduation targets in learning Al Quran Tilawati at Islamic Junior High } \\
\text { School } 1 \text { Surabaya has a predefined reference. }\end{array}$ \\
\hline 2 & $\begin{array}{l}\text { In general, the target quantity to be achieved is that all seventh-grade students for } \\
\text { two semesters have already learned basic Tilawati and memorized Al Quran juz } \\
30 \text {. }\end{array}$ \\
\hline 3 & $\begin{array}{l}\text { While the quality target of graduation, namely that students can read the Koran in } \\
\text { a tartile manner, has not been achieved. }\end{array}$ \\
\hline 4 & $\begin{array}{l}\text { The curriculum for learning Al Quran Tilawati at Islamic Junior High School } 1 \\
\text { Surabaya is operationally handed over to Al Quran teachers, madrasas provide } \\
\text { general targets. }\end{array}$ \\
\hline 5 & $\begin{array}{l}\text { Student learning load } 4 \text { times face to face in one week with a duration of } 45 \\
\text { minutes per meeting. }\end{array}$ \\
\hline 6 & Stuc \\
\hline 7 & $\begin{array}{l}\text { Islamic Junior High School } 1 \text { Surabaya education calendar. Islamic Junior High } \\
\text { School } 1 \text { Surabaya has been designed in one learning year and has been detailed } \\
\text { in daily, weekly, monthly, and new school year programs. }\end{array}$ \\
\hline 8 & $\begin{array}{l}\text { MS of managing Al-Quran learning in one class group the average number of } \\
\text { students is more than } 19 \text { children. }\end{array}$ \\
\hline
\end{tabular}

\section{The Process of Chasing Al-Quran Model Tilawati at Junior High School 34 of Surabaya}

The purpose of the Al Quran learning activity program is as a means to instill the character of students who are accustomed to reading the holy book and active in worship. As stated by the principal as follows.

"The purpose of this Al Quran learning program is to create students who have faith and piety by the vision and mission of the school. As a means of delivering students to be able to read the Al Quran and become a habit of reading the holy book. (W. Principal. 28 October 2019). " 
The learning objectives of the Al-Quran that have been set by the institution, the next steps taken by the teachers to make the Al Quran Tilawati learning activity program in more detail as conveyed by the teacher Tutik as follows;

Learning Al-Quran here is the main objective so that students read fluently "Al Quran in tajwid, so the program that we make specifically for learning Al Quran activities for students with material that has been announced as in the Tilawati curriculum, there are no other programs such as teacher training programs, graduation and khataman students. " (W. Al Quran Tilawati teacher continued February 13, 2020).

From some of the descriptions of the data above, the research findings on the third focus, about the learning process of the Quran, the recitation model at Junior High School 34 of Surabaya can be shown as Tabel 8 .

Table 8. Learning Al-Quran Model of Tilawati in Junior High School 34 of Surabaya.

\begin{tabular}{cl}
\hline No. Learning Al-Quran Model of Tilawati \\
\hline 1 & $\begin{array}{l}\text { The target of graduation is expected that all students for } 4 \text { semesters have } \\
\text { mastered basic training } \\
\text { The target of learning Al-Quran at Junior High School } 34 \text { of Surabaya has been } \\
\text { determined in terms of quantity and quality }\end{array}$ \\
3 & $\begin{array}{l}\text { The quantity and quality targets expected in the implementation have not been } \\
\text { maximally achieved } \\
\text { The Al Quran learning program at Junior High School } 34 \text { of Surabaya has a }\end{array}$ \\
5 & $\begin{array}{l}\text { curriculum structure that must be taken by students } \\
\text { he Al Quran learning program at Junior High School } 34 \text { of Surabaya has not } \\
\text { been going well }\end{array}$ \\
6 & $\begin{array}{l}\text { The children's learning load in one week, for now, runs one face to face } \\
\text { The educational calendar for the Al Quran learning program is not structured } \\
\text { separately but follows the existing education calendar in schools } \\
\text { The number of students in the class group at Junior High School } 34 \text { of Surabaya }\end{array}$ \\
9 & $\begin{array}{l}\text { is on average more than } 20 \text { children. } \\
\text { The setting of learning hours for Al-Quran at Junior High School } 34 \text { of Surabaya }\end{array}$ \\
10 & $\begin{array}{l}\text { The one week is carried out } 1 \text { face-to-face. } \\
\text { formation of children sitting face to face in lined up from right to left. }\end{array}$
\end{tabular}

Based on the analysis of the learning culture, learning management, and the Tilawati Model learning process from the three schools, namely at Junior High School Al Muslim of Sidoarjo, Islamic Junior High School of 1 Surabaya, and Junior High School 34 of Surabaya above, can be analyzed across cases of research findings in each table that has been presented above. So that it can be re-analyzed the final findings for the three research focuses. The focus of the first research regarding the culture of Tilawati learning obtained the final results of the findings of the three schools, namely, Al-Quran learning program policies that are supported by clear objectives, planning, programs and periodic evaluation and the existence of sufficient budget allocations that can be implemented properly. In making a good education it is necessary to have graduates or students of good educational character as well. To obtain this character education, a policy is needed in planning learning (Ikhwan et al., 2019). 
Furthermore, for the second focus of research on the management of Tilawati learning from the three schools, the final findings were obtained, namely the use of management functions which include planning, organizing, actuating, and controlling to provide a more systematic and measurable direction in the implementation of the management of Al-Quran learning. Tilawati learning requires several stages of the learning process including initial activities, core activities, and closing activities, this is adjusted to good planning (Khannah \& Waqfin, 2019).

Then, to focus on the third research regarding the Tilawati learning process from the three schools, the final findings were obtained, namely, the existence of a graduation target, the determination of the curriculum as a reference, the number of face-to-face meetings that was sufficient to the target, the maximum number of students was 15 in one group, teaching and learning activities were carried out. with stages by the provisions, as well as supported by adequate infrastructure and the implementation of gradual evaluations will provide smoothness in the learning process of the Qur'an with the Tilawati model. The achievement of character learning can be seen from the results of graduates of an education (Barus \& Munkasi, 2019). In improving students' understanding of learning, several stages are needed to achieve student learning achievement (Ni'mah \& Ashoumi, 2019; Saihu, 2019).

This research implies that it can be used as material to further improve the implementation of Al-Quran learning culture by developing modern learning management principles for heads of education offices, principals, teachers, teachers of al-Quran especially for Junior High School Al Muslim Sidoarjo, Islamic Junior High School 1 Surabaya, and Junior High School 34 Surabaya.

\section{CONCLUSIONS}

Based on the results of the research that has been done, it can be concluded that 1) The culture of learning Al-Quran with the Tilawati model gives a good enough contribution to fostering student character, 2) The use of management science principles in the implementation of the Al Quran learning program with the Tilawati model is very appropriate, 3) The process Learning Al-Quran model of Tilawati consists of interrelated components including; graduation targets about quality and quantity, curriculum, management of Tilawati model of Al Quran learning, 4) To foster 25 characters of students through learning the Qur'an model of Tilawati is done by designing learning with syntax or learning stages that are systematically arranged. This research management culture is limited to 3 schools, namely Junior High School Al Muslim Sidoarjo, Islamic Junior High School 1 Surabaya, and Junior High School 34 Surabaya. Through some of the research results obtained, future research can be carried out regarding the application of learning stages by combining the three schools selected as research subjects.

\section{ACKNOWLEDGEMENTS}

The research team would like to thank all leaders at the Faculty of Education Management, the State University of Surabaya, as well as all leaders and colleagues at Junior High School Al Muslim Sidoarjo, Islamic Junior High School 1 Surabaya, and Junior High School 34 Surabaya who have provided the opportunity to conduct related research. learning management culture. 


\section{REFERENCES}

Adawiah, R. (2018). Instilling the environmental care characters to the elementary schools located an the rivers banks. Journal of Wetlands Environmental Management 6(1), 84-92.

Antonia, M., Lamers, R., Wilfried, F., Admiraal., \& Roeland, M. (2020) Expatriate academics and transnational teaching: the need for quality assurance and quality enhancement to go hand in hand, Higher Education Research E Development, 39(4), 733-747.

Anwar, C., Saregar, A., Hasanah, U., \& Widayanti, W. (2018). The effectiveness of islamic religious education in the universities: The effects on the students' characters in the era of industry 4.0. Jurnal Keguruan dan Ilmu Tarbiyah, 3(1), 7787.

Barus, G., \& Mungkasi, S. (2019). On the publication of research papers in the area of character education. International Journal of Mechanical Engineering and Technology, 10(3), 1630-1635.

Che-Noh, M.A., Kasan, H., Yusak, Y.M., \& Yusuf, S.A.M. (2019). Strategic management of Qur'anic recitation teaching among primary school teachersin Malaysia. Journal of Islamic Education, 3 (1), 1-8.

Cheung, W.C., \& Hew, K.F. (2011). Design and evaluation of two blended learning approaches: Lessons learned. Australian Journal of Educational Technology, 8, 13191337.

Dalmeri. (2014). Pendidikan untuk pengembangan karakter, telaah terhadap gagasan Thomas Lickona dalam educating for character. Jurnal Al-Ulum IAIN Sultan Amai Gorontalo, 14(1), 269-288.

Deswati, Suwondo, \& Firdaus L.N. (2020). Student growth of care characters of students 'environment in the lisambil discussion in State Junior High School 21

Pekanbaru. Journal of Educational Sciences, 4(1), 93-105.

Faud, M. (2014). Agama dan pendidikan karakter: Pengembangan keilmuan dan kompetensi program studi pada UIN Sunan Kalijaga Yogyakarta. Jurnal Pendidikan Agama Islam, 11(2), 149-168.

Firestone, A.R., Rebecca, A., Cruz., \& Janelle, E. (2020). Teacher study groups: an integrative literature synthesis. Review of Educational Research, 90(5), 675- 709.

Fua, J.La., Nurlila, R.U., Ratna \& Wekke, I.S. (2018). Strategy of islamic education in developing character building of environmental students in Indonesia. Earth and Environmental Science, 175, 1-7.

Hakim, R. (2014). Pembentukan karakter peserta didik melalui pendidikan berbasis Al Quran. Jurnal Pendidikan Karakter, 4(2), 123-136.

Ikhwan, A. (2014). Integrasi pendidikan islami (Nilai-Nilai islami dalam pembelajaran), Jurnal Pendidikan Islam, 2(2), 179-194.

Ikhwan. A., Ju'subaidi., \& Rohmad, A. (2019). Development of curriculum keaswajaan (Nahdlatul 'Ulama) in character formation : In Global Perspectives on Teaching and Learning Paths in Islamic Education. IGI Global, 1(1), 92-117.

Jennifer, G., Adam. L., Maxwell, S., Julie, B., Hywel, E., \& David, L. (2017). Effects of professional development on the quality of teaching: Results from randomised controlled trial of quality teaching rounds. Teaching and Teacher Education, 68, 99-113. 
Kane, M., Frauke, M., Esther, S.Y., Christine, M., \& Rubie, D. (2017). Subjectivity of teacher judgments: Exploring student characteristics that influence teacher judgments of student ability. Teaching and Teacher Education, 65, 48-60.

Khannah, S.N., \& Waqfin, M.S.I. (2019). Penerapan metode Tilawati dalam pembelajaran Al-Qur'an dan kemampuan baca Al-Quran santri di TPQ Darussalam Kepanjen Jombang. Journal of Education and Management Studies, 2(6), 1-6.

Lemke-Westcott, T., \& Johnson, B. (2013). When culture and learning styles matter: A Canadian university with Middle-Eastern students. Journal of Research in International Education, 12(1), 66-84.

Lyer, R.B. (2017). Value-based education: Professional development vital towards effective integration. Journal of Research $\mathcal{E}$ Method in Education, 1(1), 17-20.

Malik. M., Rahim. R., Bactiar, N., \& Fahmy, R. (2015). Measuring student perception to personal characters building in education:An Indonesia case In implemetating new curiculum in high school. Science Direct Procedia-Social and Behavioral Sciences, 211, 851-858.

Ni'mah, K., \& Ashoumi, H. (2019). Strategi Peningkatan prestasi belajar nahwu kelas II Ula di Madrasah Diniyah pondok pesantren Putri Al-Lathifiyyah 1 Bahrul 'Ulum. Journal of Education and Management Studies, 2(5), 55-58.

Othman, A., Hussien, S., Ahmad, I.S., Rashid, A.A., \& Badzis, M. (2017). Islamic integrated education system model in the Malay archipelago: Implications for educational leadership. Intellectual Discourse, 25(1), 203-226.

Quan, R., Smailes, J., \& Fraser, W. (2013). The transition experiences of direct entrants from overseas higher education partners into UK universities. Teaching in Higher Education, 18(4), 414- 426.

Rokhman, F., Hum, M., \& Syifudin, A. (2014). Character education for golden generation 2045. Procedia - Social and Behavioral Sciences, 141, 1161-1165.

Rokhmana, F., Humb, M., Syaifudinc, A., \& Yuliatid. (2014). Character education for golden generation 2045. Procedia Social and Behavioral Sciences, 141(25), 1161-1165.

Saihu. (2019). Implementasi manajemen balanced scorecard di pondok pesantren Jam'iyyah Islamiyyah Tangerang Selatan. Mumtaz, 3,(1), 1-22.

Sofian, A. (2018). Internalization of character Education in the SMPIT As-syifa Boarding School. Jurnal Pendidikan Sains Sosial dan Kemanusian, 11(1), 47-62.

Sulaiman, A., \& Wibowo, U.B. (2016). Implementasi sistem penjaminan mutu internal sebagai upaya meningkatkan mutu pendidikan di universitas Gadjah Mada. Jurnal Akuntabilitas Manajemen Pendidikan, 4(1), 17-16.

Umi, F., Sri, N., \& Lisdiana. (2018). The Adiwiyata school"s role in the development of character caring for the environment (A case study at the Junior High School 6 Tuban). Journal of Innovative Science education, 7(1), 54 -62.

Utomo, Y., \& Juul, E. (2017). Habituation model of implementing environmental education in elementary school. Jurnal Pendidikan Indonesia, 6(2), 206-212.

Zainal. A., \& Sujak, (2011). Panduan \& aplikasi pendidikan karakter. Yrama Widya, Bandung. 
*Dr. Umar Jaeni (Corresponding Author)

Doctoral Program of Education Management

Universitas Negeri Surabaya

Jl. Raya Kampus Unesa, Lidah Wetan, Kec. Lakarsantri, Surabaya, Indonesia Email: umarjaeni16070976010@mhs.unesa.ac.id

Prof. Dr. Ismet Basuki

Universitas Negeri Surabaya

Jl. Raya Kampus Unesa, Lidah Wetan, Kec. Lakarsantri, Surabaya, Indonesia

Email: ismetbasuki@unesa.ac.id

Prof. Dr. Moedjiarto

Universitas Negeri Surabaya

Jl. Raya Kampus Unesa, Lidah Wetan, Kec. Lakarsantri, Surabaya, Indonesia

Email: moedjiarto@unesa.ac.id 